\title{
Students' Classroom Participation: What Drives It?
}

\author{
Dr. Siti Maziha Mustapha \\ Associate Professor, Infrastructure University Kuala Lumpur (IUKL), Malaysia \\ maziha@iukl.edu.my
}

\begin{abstract}
What drives students to engage in dialogues, contribute to discussion, and make enquiries in the classroom? Is the student's self-efficacy linked to their actual participation in class? The relationship between students' self-efficacy and classroom participation has received relatively little attention and has not been fully explored. Due to the scant literature, this study looks at self-efficacy as theorized by Bandura's Social Cognitive theory, in relation to students' participation in classroom activities. It seeks to determine whether Bandura's theory of self-efficacy has a causal relationship with students' frequency and length of participation. Eighty four students were involved in the study. All the participants completed the Classroom Participation Self-Efficacy Scale (CPSES) to determine their self-efficacy level. The videorecording sessions provided the data on the frequency and time spent on classroom participation. The quantitative data were analysed using SPSS Statistics 17.0 software, where descriptive statistics and linear regression analyses were carried out. The results showed that there was a significant relationship between students' classroom participation selfefficacy and length of participation. There was also a significant relationship between students' classroom participation self-efficacy and frequency of participation. Recommendations are offered to enhance students' self-efficacy and promote students' classroom participation in context of higher learning.
\end{abstract}

Keywords: Students' classroom participation, self-efficacy

\section{Academic Discipline And Sub-Disciplines}

Education

\section{Council for Innovative Research}

Peer Review Research Publishing System

\section{Journal: INTERNATIONAL JOURNAL OF RESEARCH IN EDUCATION METHODOLOGY}

Vol.5, No.3

www.cirworld.org/journals, ijremeditor@gmail.com 


\section{INTRODUCTION}

Classroom participation has been found to be one of the factors related to effective learning and to result in more positive views of the learning experience (Sadker \& Sadker, 1994). An active participation in class discussion encourages students to think critically about course material and to synthesize this new material with their previously held beliefs and knowledge. Despite the importance often assigned to participation in classroom discussions, it has been repeatedly reported in many studies, most students do not participate. Thus, questions arise; what drives students to participative in the classroom? Is the student's self-efficacy linked to their actual participation in class? Past researchers have proven that "self-efficacy beliefs are strong predictors of behaviour" (Hoy, 2004). Students who have the beliefs that they are capable of interacting with their educators and peers are likely to be participative and academically engaged. The purpose of the study is to explore students' classroom participation and its relationship with their self-efficacy. It seeks to determine whether Bandura's theory of self-efficacy, has a causal relationship with students' frequency and length of participation.

\section{LITERATURE REVIEW}

The ability to communicate with lecturers and peers can be a major component of academic success, as lecturer-student communication and student-student communication are the primary means of learning in classrooms especially at tertiary level. Students who have difficulty in communicating because they do not believe that they have the abilities to interact with educators and other students in class may opt for non-participation, thus affecting their academic performance. According to Long, Stinson and Braeges (1991), nonparticipation can adversely affect students' learning and eventual academic success.

One of the main foci of educators is to get students to actively participate in class so they can reap the benefits of verbal interactions in class. Petress (2006) asserted that "class participation is one major vehicle towards achieving quality learning" (p. 823). Educators should focus on student participation in the classroom because learning is an active process (Junn, 1994). What concerns educators is students' inability to carry out the task of participating in classroom activities well, which is reflected in their passivity. According to Bosacki (2005), silence is one of the most frustrating and disconcerting classroom phenomena. She explained that when students will not or cannot actively engage in classroom discourse, it could disrupt and interrupt the dialogical situations that transform classrooms into caring and compassionate communities. The absence of dialogue or voice, which forms the foundation of most classroom activities, could be undesirable or detrimental.

Past researchers have proven that "self-efficacy beliefs are strong predictors of behaviour" (Hoy, 2004). Students who have the beliefs that they are capable of interacting with their educators and peers are likely to be participative and academically engaged. The concept of self-efficacy, as originated by Albert Bandura of Stanford University, refers to a person's beliefs concerning his or her ability to successfully perform a given task or behavior (Bandura, 1977, 1997). Selfefficacy has been used in understanding and facilitating students' academic performance as many studies (Chemers, Hu \& Garcia, 2001; Greene \& Miller, 1996; Multon, Brown \& Lent, 1991) supported a positive connection between self-efficacy and academic achievement. According to Bandura, individuals' self-efficacy will influence how they ultimately approach and perform the task. Although many of these students may possess the requisite level of knowledge and skills to participate in class, few perform at an optimum level. This may be reflective mostly of a variance in self-efficacy as one's belief in his or her own capabilities will determine whether one can perform a certain task (Bandura, 1982). Therefore, it can be assumed that the students' classroom participation self- efficacy will determine their actual participative behaviour.

When students are highly self-efficacious, they become active in class. When students are involved in their learning process, they have a sense of control over the outcome. Consequently, they have the tendency to believe that they have a good chance of succeeding in their academic pursuits. Petress (2006) stressed that students need active classroom involvement because they have been shown to retain what they do better than retain what they vicariously learn. Participation has been found to be an indirect indicator of student achievement (Voelkl, 1995). That is, students who participate in class tend perform better on exams (Reinsch \& Wambsganss, 1994), are more motivated (Junn, 1994), and possess more confidence in the classroom (Fassinger, 1995).

Despite the importance often assigned to participation in classroom discussions, as repeatedly reported in many studies, most students do not participate (e.g., Caspi, Chajut, Saporta, \& Beyth-Marom, 2006; Crombie, Pyke, Silverthorn, Jones, \& Piccinin, 2003; Gorsky, Caspi, \& Trumper, 2004). For example, at the college level typically only 10 students in a class of 40 participate in discussion, and interaction is dominated by 5 of these students (Karp \& Yoels, 1976). The vast majority $(80 \%)$ of the questions asked by professors are at the lowest cognitive level - that is, recall of facts (Barnes, 1983). Crombie et al. (2003) reported that $64 \%$ of the students never, rarely, or only occasionally asked or responded to a question in the classroom.

From the researcher's initial observation of Malaysian university students, many of them are not active participants in classroom activities. This concurs with a study carried out in 2004 where students' participation had been minimal in frequency and "questions asked in class [were] normally met with deafening silence" (Mohd-Yusof et al., 2004). The lack of frequency in classroom participation is also found in a study carried out by Sayadi in 2007. He found that, despite the importance often assigned to participation in classroom discussions, it has been repeatedly reported in many studies that most students do not participate (2007). Only about $40 \%$ of the students would volunteer to voice their opinions or comments (2007Title and Authors 


\section{RESEARCH QUESTIONS}

In light of the information presented, the following question arises: is the student's self-efficacy linked to their actual participation in class? The relationship between students' self-efficacy and classroom participation has received relatively little attention and has not been fully explored. A question that needs to be asked is whether these studies have provided an adequate or fair test of the hypothesized relationship between self-efficacy judgments and classroom participation. Due to the scant literature on the influence self-efficacy judgments on classroom participation of university students, this study aims to look at self-efficacy as theorized by Bandura's Social Cognitive theory, in relation to students' participation in classroom activities.

\section{METHODOLOGY}

\section{Participants}

A medium sized private university with over 4,000 students enrolled in various fields was selected. The university is located in Kajang, Malaysia. A total of 291 students were included in this study. All the participants were in their first, second, and final year of studies. The participants were all Malaysian. They consented to take part in the study. The participants were briefed on the details of the study and informed that their participation was voluntary, anonymous, and the study would be carried out in strict confidentiality.

\section{Data Collection}

The participants were asked to complete the Class Participation Self-Efficacy Scale (CPSES), which took approximately 15 minutes. The researcher collected the surveys. The responses to CPSES were used to determine students' selfefficacy level.

\section{Data Analysis}

The Linear Regression analyses were carried out to determine whether there was a significant relationship between students' classroom participation self-efficacy and length of participation. The same analysis was carried out to determine whether there was a significant relationship between students' classroom participation self-efficacy and frequency of participation.

During the video-recording session, the researcher undertook the role of a non-participant observer. The investigator took concurrent field notes on the nature of interaction between students and lecturer. Since classroom participation can be operationally defined as students' level of involvement in class, the time spent and frequency were used to gauge and describe participation in this study.

1. Students' level of self-efficacy (was scored quantitatively using CPSES -Classroom Participation Self-Efficacy Scale).

2. Students' frequency and length of participation (were recorded during class).

For this study, event recording and duration recording were used to record frequency and length of participation.

\section{RESULTS}

A Simple Linear Regression analysis was carried out to find out whether independent variable classroom participation selfefficacy level was significantly correlated to the dependent variable length of participation.

\section{Relationship between Classroom Participation Self-Efficacy and Frequency of Participation}

\section{The following assumptions were checked:}

\section{Sample Size:}

To obtain a result that is generalizable, the sample size needs to be big enough. Stevens (1996) proposed 15 subjects per predictor for a reliable equation. Hair et al. (2001) gave a simple formula: $N \geq 50+8 m$ (m=number of IVs) for testing a multiple correlation. Therefore, this study required $50+8(1 \mathrm{~V})=58$ cases. In this study, 84 cases were used; thus, the sample size was appropriate.

Outliers, Normality, Linearity, Homoscedasticity and Independence of the Residuals:

The Normal Probability Plot of the Regression Standardized Residuals indicated that the points clustered along the diagonal line from the bottom left to top right. This indicated that there was no major deviation from normality.

Linearity:

There is an assumption that the relationship between dependent and independent variables follow a somewhat linear pattern. Table 1 shows linear relationship with a positive curve. 


\section{Table 1 Scatterplot}

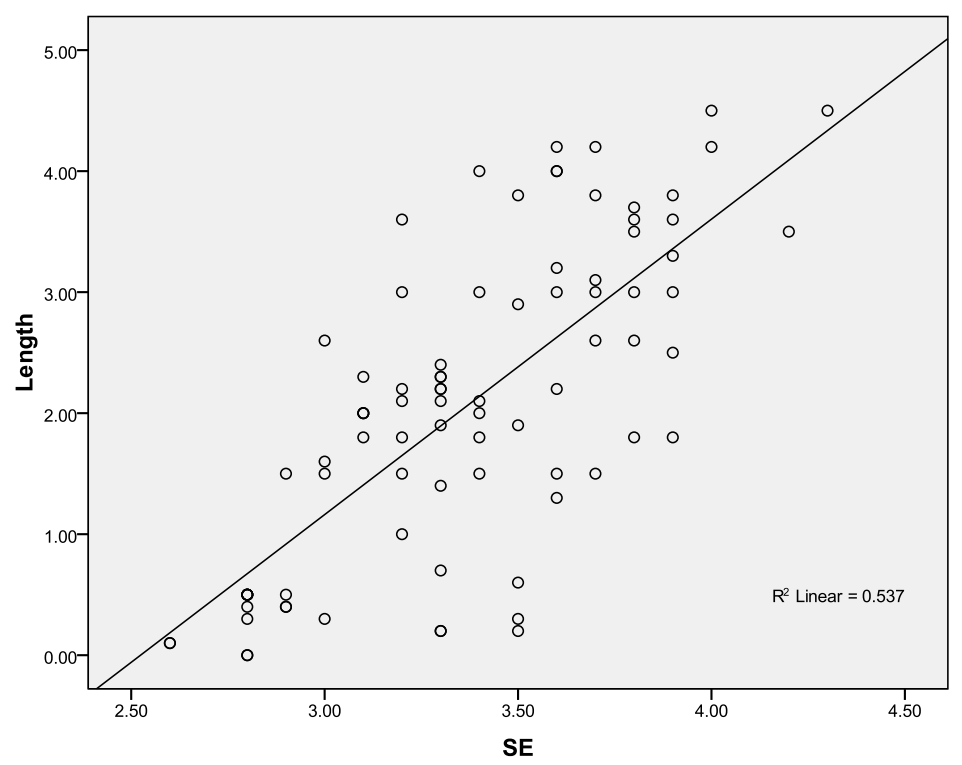

There does not appear to be any points that lie far from the cluster of data points or far from the regression line; thus there are no possible outliers or influential observations. In addition, it shows a linear relationship between the independent and dependent variable.

The residual plot shown in Table 2 indicates there is a random scatter of the points (independence) with a constant spread (constant variance). The studentized residual plot shows a random scatter of the points (independence) with a constant spread (constant variance) with no values beyond the \pm 2 standard deviation reference lines (no outliers). The normal probability plot of the residuals shows the points close to a diagonal line; therefore, the residuals appear to be approximately normally distributed. Thus, the assumptions for regression analysis appear to be met.

\section{Table 1 Residual plot}

\section{Normal P-P Plot of Regression Standardized Residual}

Dependent Variable: Length

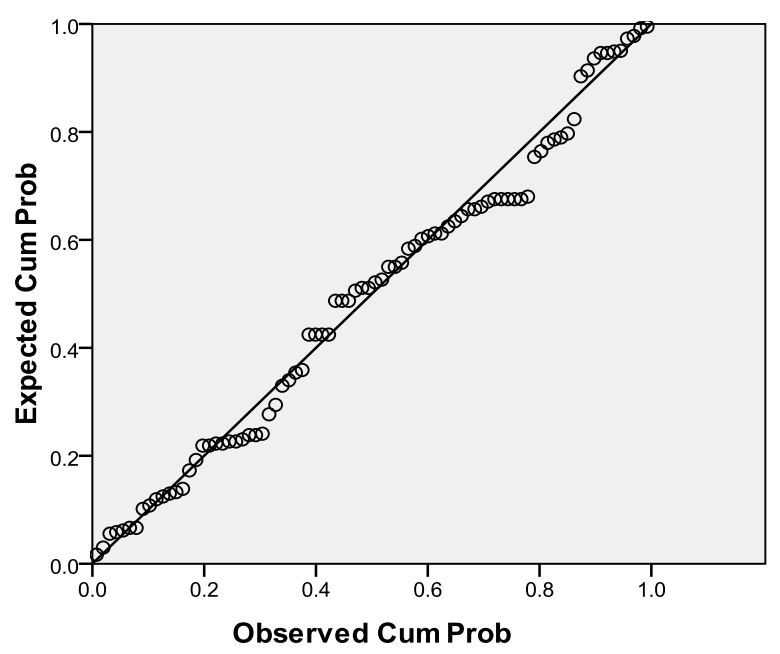


Based on Table 3, the correlation coefficient is .827. This value of $r$ suggests a strong positive linear correlation, since the value is positive and close to +1 . Since the above value of $r$ suggests a strong positive linear correlation, the data points should be clustered closely about a positively sloping regression line. This is consistent with the graph obtained above. Therefore, since we see a strong positive linear relationship between self-efficacy and length of participation, linear regression analysis can continue.

\section{Table 2 Correlations}

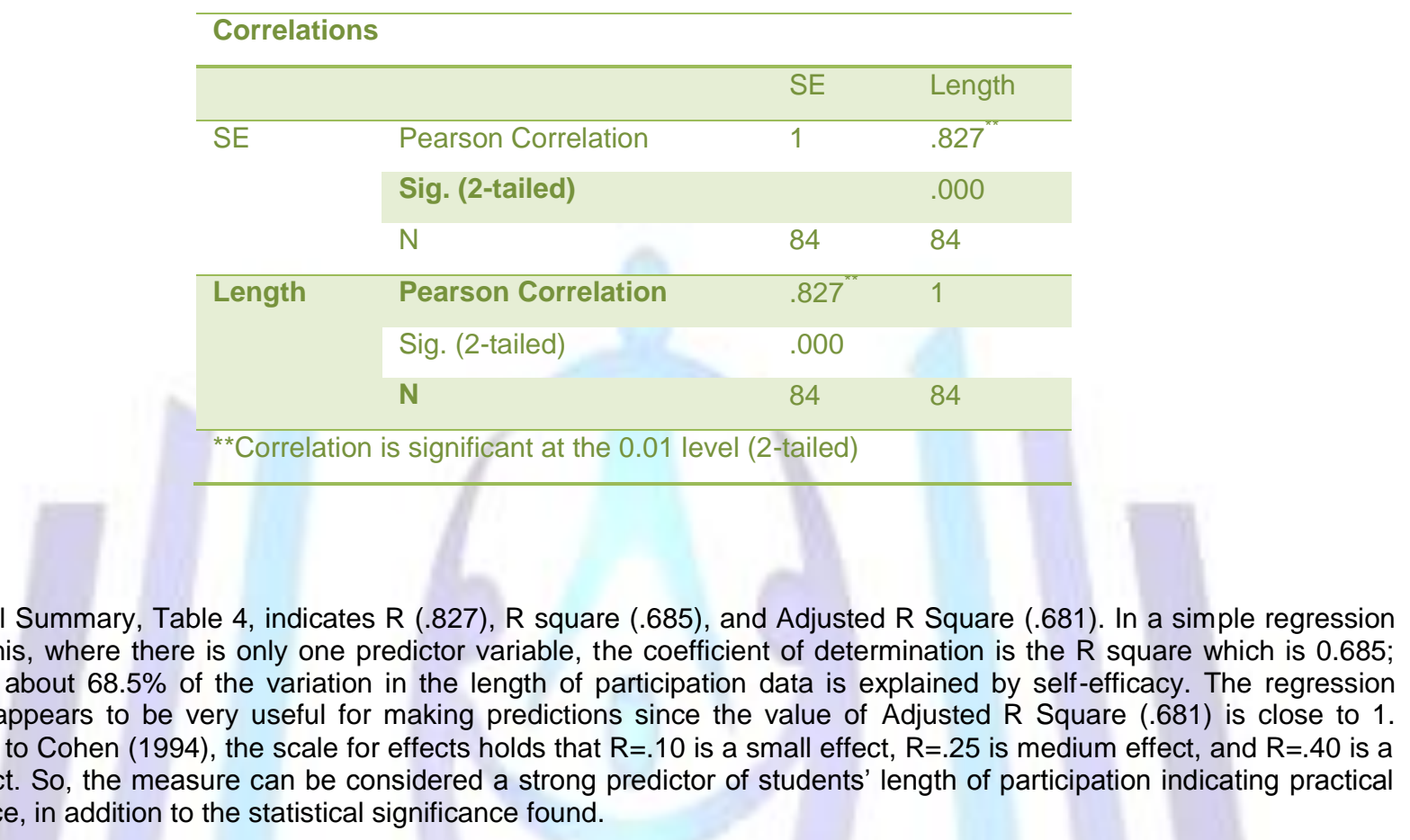

The Model Summary, Table 4, indicates R (.827), R square (.685), and Adjusted R Square (.681). In a simple regression such as this, where there is only one predictor variable, the coefficient of determination is the $R$ square which is 0.685 therefore, about $68.5 \%$ of the variation in the length of participation data is explained by self-efficacy. The regression equation appears to be very useful for making predictions since the value of Adjusted $R$ Square (.681) is close to 1 . According to Cohen (1994), the scale for effects holds that $R=.10$ is a small effect, $R=.25$ is medium effect, and $R=.40$ is a large effect. So, the measure can be considered a strong predictor of students' length of participation indicating practical significance, in addition to the statistical significance found.

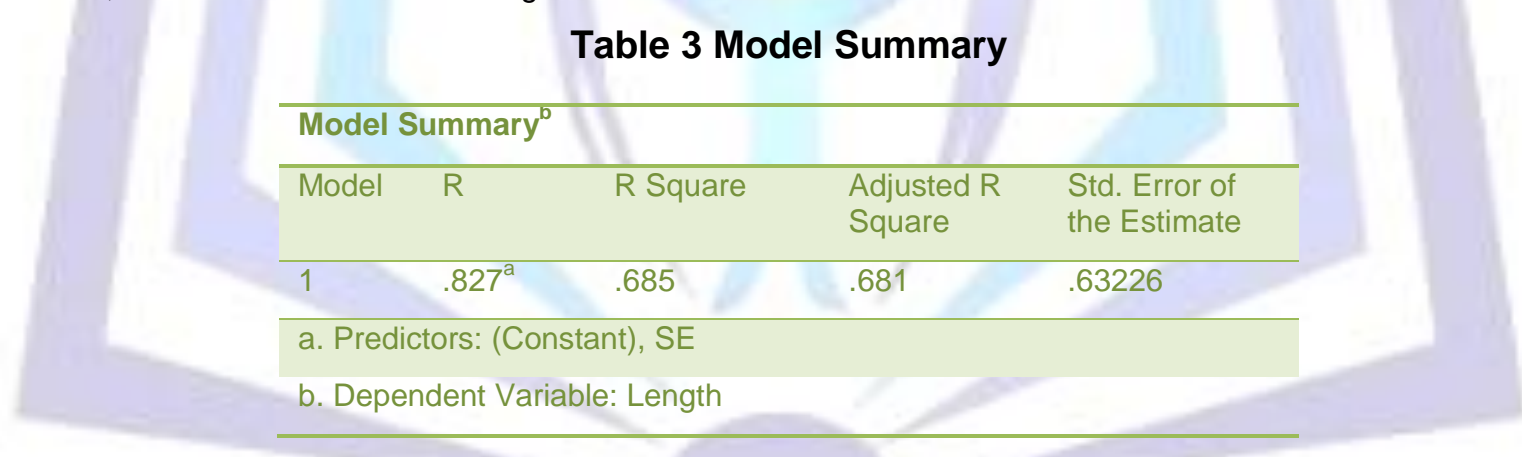

The ANOVA table (Table 5) below presents the results to test the null hypothesis that R-square is zero. It shows that the computed F statistic is 178.093 , with an observed significance level of less than 0.001 . Thus, the hypothesis that there is no linear relationship between the independent and dependent variable is rejected. 
Table 4 ANOVA

\begin{tabular}{|c|c|c|c|c|c|c|}
\hline \multicolumn{7}{|c|}{ ANOVA $^{D}$} \\
\hline Model & & $\begin{array}{l}\text { Sum of } \\
\text { Squares }\end{array}$ & df & Mean Square & $\mathrm{F}$ & Sig. \\
\hline \multirow[t]{3}{*}{1} & Regression & 71.192 & 1 & 71.192 & 178.093 & $.000^{\mathrm{a}}$ \\
\hline & Residual & 32.779 & 82 & .400 & & \\
\hline & Total & 103.971 & 83 & & & \\
\hline \multicolumn{7}{|c|}{ a. Predictors: (Constant), SE } \\
\hline \multicolumn{7}{|c|}{ b. Dependent Variable: Length } \\
\hline
\end{tabular}

Table 6 Coefficients

Coefficients

\begin{tabular}{|c|c|c|c|c|c|c|c|c|}
\hline \multirow[b]{2}{*}{ Model } & & \multicolumn{2}{|c|}{$\begin{array}{l}\text { Unstandardized } \\
\text { Coefficients }\end{array}$} & \multicolumn{3}{|l|}{$\begin{array}{l}\text { Standardized } \\
\text { Coefficients }\end{array}$} & \multicolumn{2}{|c|}{$\begin{array}{l}95.0 \% \text { Confidence } \\
\text { Interval for } \mathrm{B}\end{array}$} \\
\hline & & B & Std. Error & Beta & $t$ & Sig. & $\begin{array}{l}\text { Lower } \\
\text { Bound }\end{array}$ & $\begin{array}{l}\text { Lower } \\
\text { Bound }\end{array}$ \\
\hline 1 & $\begin{array}{l}\text { (Const } \\
\text { ant) }\end{array}$ & -6.163 & .651 & & -9.472 & .000 & -7.458 & -4.869 \\
\hline & SE & 2.541 & .190 & .827 & 13.345 & .000 & 2.162 & 2.919 \\
\hline
\end{tabular}

The coefficients table (Table 6) presents the standardized beta coefficient between the independent variable self-efficacy and the dependent variable length of participation. The Beta coefficient is shown to be positive and statistically significant at the 0.001 level. Thus, the higher the students' self-efficacy scores, the higher their length of participation scores, Beta = $.827, \mathrm{t} \_13.345, \mathrm{p}<.001$.

It can be concluded that there is a statistically significant relationship between the classroom participation self-efficacy and length of participation.

Relationship between Classroom Participation Self-Efficacy and Length of Participation:

A simple linear regression is an appropriate model of the relationship between two quantitative variables, provided the data satisfies the assumption of linearity in a scatterplot of the raw data. The scatterplot is shown in Table 7 below. 


\section{Table 5 Scatterplot}

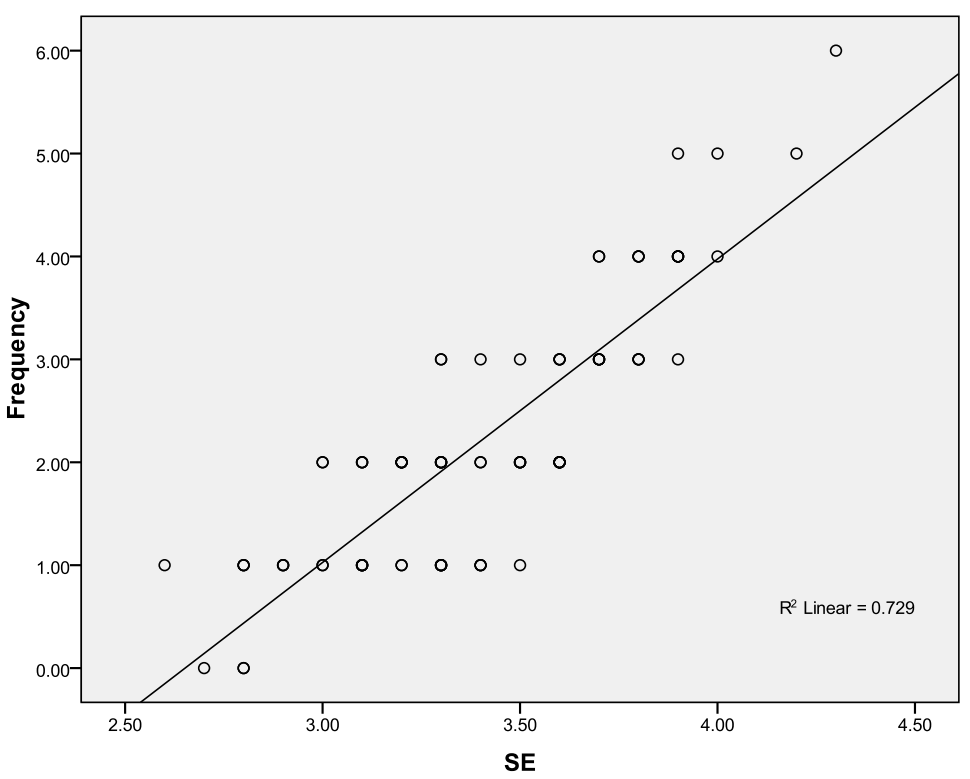

Since there were no points that lie far from the cluster of data points or far from the regression line, it can be concluded that there were no possible outliers or influential observations and there is a linear relationship.

The Scatter-plot of the Standardized Residuals showed that there were no outlying residuals because all the cases have a standardized residuals between 3.3 and -3.3 (Tabachnick \& Fidell, 2000).

Table 8 shows the normal P-P Plot of regression standardized residual.

\section{Table 6 Probability plot of the residuals}

\section{Normal P-P Plot of Regression Standardized Residual}

Dependent Variable: Frequency

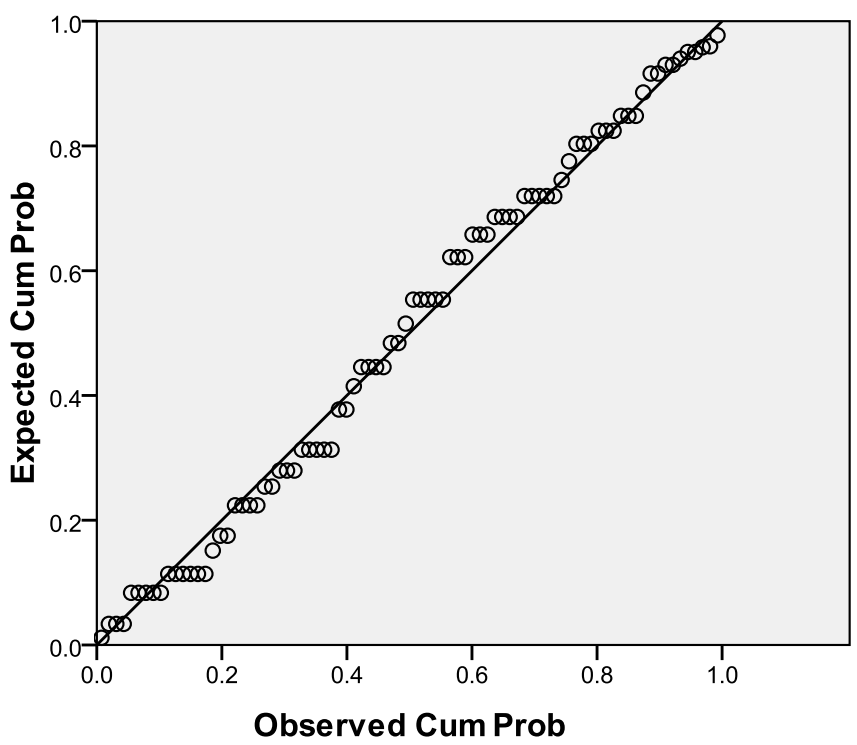


The assumptions for regression analysis appeared to be met, since the normal probability plot of the residuals showed that the points were close to a diagonal line; therefore, the residuals appeared to be approximately normally distributed.

The correlation coefficient shown in Table 9 is .854 . This value indicated a strong positive linear correlation since the value is positive and close to +1 . When there is a strong positive linear correlation, the data points should be clustered closely about a positively sloping regression line. The graph obtained above clearly showed a strong positive linear relationship, making linear regression analysis appropriate.

Table 7 Correlations

\begin{tabular}{llll}
\hline \multicolumn{1}{l}{ Correlations } & & & \\
\hline \multirow{4}{*}{ SE } & & SE & Frequency \\
& Pearson Correlation & 1 & $.854^{* *}$ \\
& Sig. (2-tailed) & & .000 \\
\cline { 2 - 3 } Frequency & $\mathrm{N}$ & 84 & 84 \\
& Pearson Correlation & $.854^{* *}$ & 1 \\
& Sig. (2-tailed) & .000 & \\
& $\mathrm{~N}$ & 84 & 84 \\
\hline${ }^{* *}$ Correlation is significant at the 0.01 level (2-tailed) \\
\hline
\end{tabular}

Applying Cohen's criteria for effect size (less than $0.01=$ trivial; 0.01 up to $0.09=$ weak or small; 0.09 up to $0.25=$ moderate; 0.25 or greater = strong or large), the relationship between the self-efficacy and frequency of participation can be characterized as a strong relationship $\left(R^{2}=72.9 \%\right)$. From Table 10 , about $72.9 \%$ of the variation in the frequency of participation data was explained by self-efficacy. Since the value of $\mathrm{R}^{2}$ is close to 1 , the regression equation can be considered a strong predictor of students' frequency of participation indicating practical significance in addition to the statistical significance found.

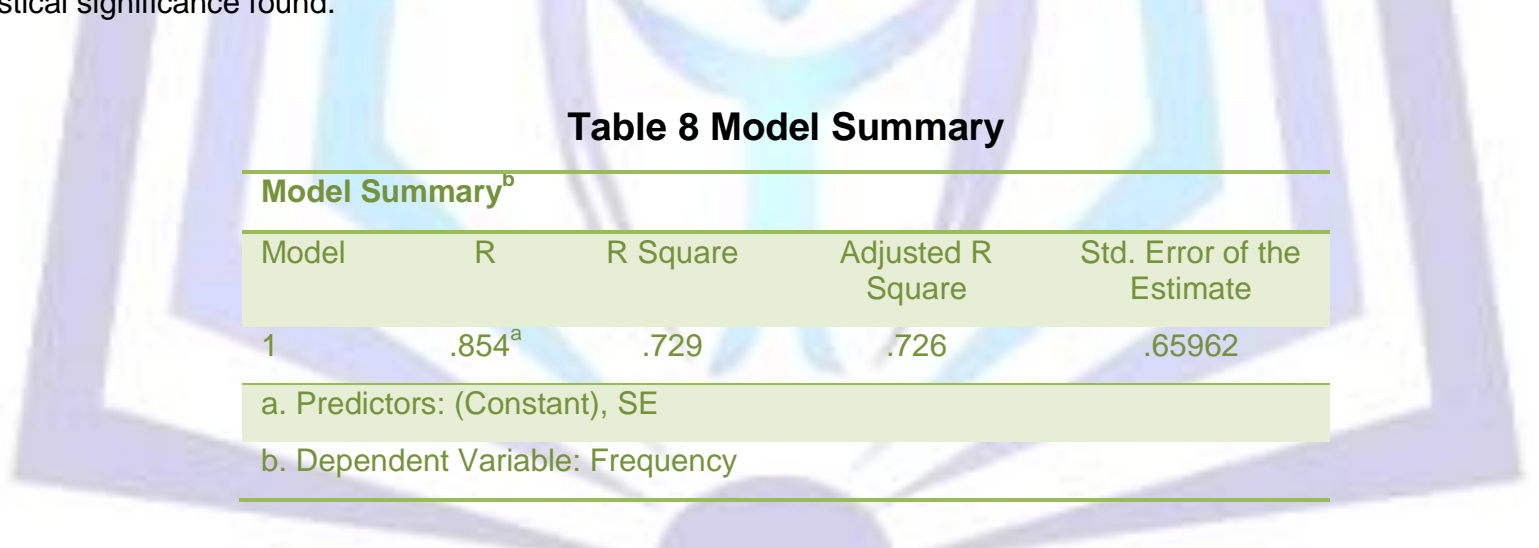

The ANOVA table below (Table 11) shows that the computed F statistic is 220.371, with an observed significance level of less than 0.001 . Thus, it can be concluded that there is linear relationship between the independent and dependent variable. 
Table 9 ANOVA

\begin{tabular}{|c|c|c|c|c|c|c|}
\hline \multicolumn{7}{|c|}{ ANOVA $^{b}$} \\
\hline Model & & $\begin{array}{l}\text { Sum of } \\
\text { Squares }\end{array}$ & df & Mean Square & $F$ & Sig. \\
\hline \multirow[t]{3}{*}{1} & Regression & 95.882 & 1 & 95.882 & 220.371 & $.000^{\mathrm{a}}$ \\
\hline & Residual & 35.678 & 82 & .435 & & \\
\hline & Total & 131.560 & 83 & & & \\
\hline \multicolumn{7}{|c|}{ a. Predictors: (Constant), SE } \\
\hline \multicolumn{7}{|c|}{ b. Dependent Variable: Frequency } \\
\hline
\end{tabular}

Table 10 Coefficients

\begin{tabular}{|c|c|c|c|c|c|c|c|}
\hline \multicolumn{8}{|l|}{ Coefficients $^{a}$} \\
\hline & \multicolumn{2}{|c|}{$\begin{array}{l}\text { Unstandardized } \\
\text { Coefficients }\end{array}$} & \multicolumn{2}{|l|}{$\begin{array}{l}\text { Standardized } \\
\text { Coefficients }\end{array}$} & & \multicolumn{2}{|c|}{$\begin{array}{l}95.0 \% \text { Confidence Interval } \\
\text { for B }\end{array}$} \\
\hline Model & B & $\begin{array}{l}\text { Std. } \\
\text { Error }\end{array}$ & Beta & $t$ & Sig. & $\begin{array}{l}\text { Lower } \\
\text { Bound }\end{array}$ & $\begin{array}{l}\text { Upper } \\
\text { Bound }\end{array}$ \\
\hline 1 (Constant) & -7.819 & .679 & & -11.517 & .000 & -9.169 & -6.468 \\
\hline SE & 2.948 & .199 & .854 & 14.845 & .000 & 2.553 & 3.343 \\
\hline
\end{tabular}

The coefficients table (Table 12) presents the standardized beta coefficient between the independent variable self-efficacy and the dependent variable frequency of participation. The Beta coefficient is shown to be positive and statistically significant at the 0.001 level. Thus, the higher the students' self-efficacy scores, the higher their frequency of participation scores, Beta $=.854, \mathrm{t} 14.845, \mathrm{p}<.001$.

The results of the analyses showed that the independent variable, classroom participation self-efficacy, is significantly correlated to frequency of participation.

\section{DISCUSSION AND CONCLUSION}

The study found a significant relationship between students' classroom participation self-efficacy and length of their actual participation. The Beta coefficient was shown to be positive and statistically significant at the 0.001 level. Thus, the higher the students' self-efficacy scores, the higher their length of participation scores, Beta $=.827, t \_13.345, p<.001$. It was also found that there was a significant relationship between classroom participation self-efficacy and frequency of participation. About $72.9 \%\left(R^{2}=72.9 \%\right)$ of the variation in the frequency of participation data was explained by self-efficacy. The scale of effects indicated a large effect (R being more than .40) according to Cohen (1994). Therefore, self-efficacy can be considered a strong predictor of students' length and frequency of participation. This significant relationship indicates that highly efficacious students participate more often and give more lengthy explanations or answers during class compared to those with low self-efficacy. This finding lends support to the study carried out by Crombieet al. (2003). They found that students categorized as active class participants perceived themselves to raise their hands more frequently, interrupt more frequently, and intervene for longer periods of time as compared to those categorized as less active. Dawson (1994) also found that frequency and length of speaking were correlated to students' academic abilities. Hence, students' frequency and length of speaking could be indicators of their academic abilities.

In summary, the findings of this research support that student's participation frequency and length differed according to their level of self-efficacy, and these beliefs led them to play different roles as participants while involving themselves in classroom activities. For instance, the more self-efficacious students are, the more frequently they initiated interaction with lecturer and other students in class. They also elaborated their answers and exhibited no haste in completing their answers. Examples were observed when students with higher levels of self-efficacy frequently answered questions, explained answers, asked questions, shared ideas, challenge others' ideas, and showed a jovial demeanour. On the other hand, less efficacious students used shorter answers, responded non-verbally, and responded only when called by the lecturer. This study highlights the fact that differences in participation patterns are caused by the differences in selfefficacy beliefs. The study is an extension of the body of research of the relationship between self-efficacy and students' participative behaviour in university classroom settings. 


\section{RECOMMENDATIONS}

Building students' self-efficacy beliefs will help students to focus more on what they can do and help them to put in more effort in what they perceive they cannot do. Bandura (1994) asserted that the stronger a person's self-efficacy, the greater capability they have to see difficult tasks as challenges rather than threats. The traditional assessment practices that emphasize students' weaknesses will not encourage students who have low self-efficacy to improve themselves. The selfefficacy data may also suggest improved instructional approaches, which can help educators to create a different approach for students whose beliefs in their skills are low as opposed to a student whose ability beliefs are high.

Therefore, self-efficacy data might make educators re-evaluate and re-direct their assessment philosophy and practice towards giving students with low self-efficacy clear evidence of how their effort affects even the smallest incremental gains in their achievement. An appropriate evaluation instrument would give a true picture of students' potential. The selfefficacy data may suggest improved instructional approaches which can help educators to create a different approach for students whose beliefs in their skills are low as opposed to a student whose ability beliefs are high. Classroom activities can be geared towards improving students' self-efficacy. By understanding how students feel about classroom participation, as well as about what and how they participate, educators could organize appropriate class activities to accommodate each student's needs and feelings, thus motivating those who are reticent to feel more efficacious towards participating in class.

\section{REFERENCES}

[1] Bandura, A. (1977). Self-efficacy: Toward a unifying theory of behavioural change. Psychological Review, 84(2), 191-215. doi: 10.1037/0033-295X.84.2.191

[2] Bandura, A. (1982). Self-efficacy mechanism in human agency. American Psychologist, 37(2), 122-147. doi: 10.1037/0003-066X.37.2.122

[3] Bandura, A. (1997). Self-efficacy: The exercise of control. New York: W. H. Freeman.

[4] Barnes, C. P. (1983). Questioning in college classrooms. In C. L. Ellner \& C. P. Barnes (Eds.), Studies of college teaching: experimental results, theoretical interpretations, and new perspectives (pp. 61-82). Lexington, MA: D. C. Heath.

[5] Bosacki, S. L. (2005). The culture of classroom silence. New York: Peter Lang.

[6] Caspi, A., Chajut, E., Saporta, K., \& Beyth-Marom, R. (2006). The influence of personality on social participation in learning environments. Learning and Individual Differences, 16(2), 129-144. doi: 10.1016/j.lindif.2005.07.003

[7] Chemers, M. M., Hu, L., \& Garcia, B. F. (2001). Academic self-efficacy and first-year college student performance and adjustment. Journal of Educational Psychology, 93(1), 55-64.

[8] Cohen, J. (1994). The earth is round ( $<$.05). American Psychologist, 49(12), 997-1003. doi: 10.1037/0003066X.49.12.997

[9] Crombie, G., Pyke, S. W., Silverthorn, N., Jones, A., \& Piccinin, S. (2003). Students' perception of their classroom participation and instructor as a function of gender and context. Journal of Higher Education, 74(1), 51-76.

[10] Dawson, D. L. (1994). Student-teacher interaction in the case-method classroom. Unpublished doctoral dissertation, University of Western Ontario, London, Ontario, Canada.

[11] Fassinger, P. A. (1996). Professors' and students' perceptions of why students participate in class. Teaching Sociology, 24(1), 25-33. doi: 10.2307/1318895

[12] Gorsky, P., Caspi, A., \& Trumper, R. (2004). Dialogue in a distance education physics course. Open Learning, 19(3), 265-277. doi: 10.1080/0268051042000280129

[13] Greene, B. A., \& Miller, R. B. (1996). Influences on achievement: Goals, perceived ability, and cognitive engagement. Contemporary Educational Psychology, 21(2), 181-192. doi: 10.1006/ceps.1996.0015

[14] Hair, J. F., Black, W. C., Babin, B. J., Anderson, R. E., \& Tatham, R. L. ( 2006). Multivariate Data Analysis (6th ed). New York: Macmillion Publishing Company.

[15] Hoy, A. W. (2004, April). What do teachers need to know about self-efficacy? Paper presented at the Annual Meeting of the American Educational Research Association, San Diego, CA.

[16] Junn, E. (1994). "Pearls of wisdom": Enhancing student class participation with an innovative exercise. Journal of Instructional Psychology, 21(4), 385-387.

[17] Karp, D. A., \& Yoels, W. C. (1976). The college classroom: Some observations on the meaning of student participation. Sociology and Social Research, 60, 421-439.

[18] Long, G, Stinson M.S., \& Braeges, J. (1991). Students' perception of communication ease and engagement: How they relate to academic success. American Annals of the Deaf, 136(1), 414-421.

[19] Mohd-Yusof, K., Abdul-Aziz, A., Abdul-Hamid, M. K., Abu-Hassan, M. A., Hashim, M. H., Syed-Hassan, S. A. H., \& Azila, N. M. A. (2004). Problem based learning in engineering education: A viable alternative for shaping graduates for the 21st century? Paper presented at the Conference on Engineering Education, Kuala Lumpur, MY. 
[20] Multon, K. D., Brown, S. D., \& Lent, R. W. (1991). Relation of self-efficacy beliefs to academic outcomes: A metaanalytic investigation. Journal of Counselling Psychology, 38(1), 30-38. doi: 10.1037/0022-0167.38.1.30

[21] Petress, K. (2006). An operational definition of class participation. College Student Journal, 40(4), 821-823.

[22] Reinsch, R., \& Wambsganss, J. R. (1994). Class participation: How it affects results on examination. Journal of Education for Business, 70(1), 33-37. (ERIC No. EJ490529)

[23] Sayadi, Z. A. (2007). An investigation into first year engineering students' oral classroom participation. A case study. Unpublished master's thesis, Universiti Teknologi Malaysia, Faculty of Education.

[24] Stevens, J. (1996). Applied multivariate statistics for the social sciences. (3rd ed.). Mahwah, NJ:Lawrence Erlbaum Associates.

[25] Tabachnick, B. G., \& Fidell, L. S. (2000). Using multivariate statistics (4th ed.). New York: Harper-Collins.

[26] Voelkl, K. E. (1995). School warmth, student participation, and achievement. Journal of Experimental Education, 63(2), 127-138. doi: 10.1080/00220973.1995.9943817

\section{Author' biography with Photo}

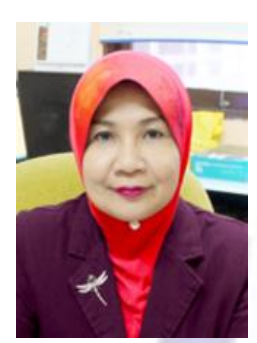

Associate Professor Dr. Siti Maziha Mustapha is an academician and a researcher. Her main areas of interests are social interactions, teaching and learning and education branding. She is currently involved in researches on internationalization, branding and educational practices.

Apart from that, Associate Professor Dr. Siti Maziha is actively conducting short courses, doing consultations, publishing journal articles and presenting conference papers. 